技術報告

\title{
ピックル注入法におけるハム類の品質に対する重合リン 酸塩添加量の影響十
}

\author{
新村 裕 $^{*}$ ・山田順一*・藤井静江 ${ }^{*}$. 春日谷郷子* ・高坂和久*
}

\section{The Effect of the Addition of Polyphosphate on Quality of Cooked Cured Pork Loins on the Pickle Injection Method ${ }^{\dagger}$}

\author{
(Studies on the Manufacturing Process of Cooked Cured Hams by a \\ Multiple Pickle Injector Part IV)
}

\author{
Yutaka Shinmura*, Junichi Yamada*, Shizue FujiI*, \\ Kyoko Kasugaya* and Kazuhisa KoHsaKa* \\ * Japan Meat Processors' Association, 5-6, Ebisu 1 chome, Shibuya-ku, Tokyo 150
}

\begin{abstract}
This work was undertaken to obtain technological information on the manufacturing process of hams by a multiple pickle injector. In this paper, the effect of polyphosphate added in loins injected with pickle on water holding capacity, color forming ratio, remaining rate of $\mathrm{NO}_{2}^{-}$and others was investigated. (1) Water holding capacity of cooked cured loin with $2 \% \mathrm{NaCl}$ increased significantly with an increase of the amount of polyphosphate injected. An addition of polyphosphate in the amount of $0.3 \%$ or more maintained a relatively high constant level of water holding capacity of loin. (2) Cut surface of cooked cured loin having $0.5 \%$ of polyphosphate was considerably lowered in Hunter $L$ and $b$-values in comparison with that having no polyphosphate. (3) The remaining rate of $\mathrm{NO}_{2}^{-}$in loin increased with an increase of the amount of polyphosphate, on the contrary, the color forming ratio was lowered. Particularly, the injection of $0.5 \%$ or more of polyphosphate induced a marked lowering of color forming ratio. (4) It was found that the distribution of polyphosphate in loin injected with pickle was uneven, indicating a partially high content of polyphosphate.
\end{abstract}

(Received Dec. 11, 1980)

八厶類の塩浿にマルチタイブピックルインジェクター を利用することによって製品品質の均一化や安定化, 塩 漬期間の短縮化, 塩漬剂添加量の調節など優れた技術 的, 経済的効果が得られた。また, 従来の加工法では汪 とんど利用できなかった添加物類も使用可能となった。 その添加物の一つとして重合りン酸塩がある。ソーセー ジの製造では必要不可久とる言えるほど利用されている
が，八ム類では 20 年ほど前から研究報告119) はあるもの の、ほとんど利用されることはなかった。しかし、最近で は重合リン酸塩の利用頻度が高くなっているす。年の背 景として第一は低食塩の製品が好まれる傾向がある。最 近の調查) ではロース八ムの食塩合量が $2.4 \%$ (1966年 の平均值) から $2.1 \%$ (1978 年の平均值) に減少してお り，この低食塩合量では十分な保水力を維持することが

*（社）日本食肉加工協会（广150 東京都渋谷区恵比寿 1 丁目 5 番 6 号） 
できない。第二は加工原料肉として低廉で，品質が比較 的安定している输入冷涷肉の利用が増加していることで ある。この冷涷肉は新鮮な国内産豚肉よりも一般に保水

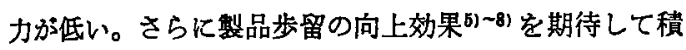
極的に利用される傾向るある。そのため重合リン酸塩の 添加過剩に基因する变化を指摘する報告がある9。

重合リン酸塩はハム類の加工に必要不可欠な添加物で

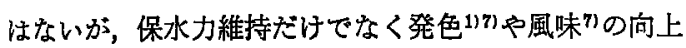
効果，酸化防止効果78)10) などの作用がある。

以上のような現況から，本試験ではハム類製造におけ る重合リン酸塩の影響を検討するために保水力, 亜硝酸 根残存率，発色率などに及ぼす影響を調査した。なお， 供試重合リン酸塩は高濃度食塩水に溶解させる必要性か らトリポリリン酸ナトリウムを主成分とし，市販リン酸 塩製削に準拠して混合調製した。

\section{実 験 方 法}

\section{1. 試料の調製}

前報11で示したようにしまり，きめ，肉色などの肉眼 的判定から中程度以上の品質持つ市肘の豚ロース肉安 選び，肩部から腰部を一定の肉片（長さ約 $15 \mathrm{~cm}$, 幅的 $13 \mathrm{~cm}$, 厚さ約 $7 \mathrm{~cm}$, 重量約 $1 \mathrm{~kg}$ ）になるように 4 分 割した。供試材料に及ぼす個体の影恠をできるたけ少な くするためにラテン方格法12)で各処理区に分配した。そ して次の 3 種のピックルを調裴し，保水力への影響は (1) (3)のビックルを注入した試料で検討した。亜硝酸根 残存率, 発色率, 肉色への影響は(3)のピックル注入部で 検討した。また，無機リンの分布は (1) のピックルのう ち, 重合リン酸塩濃度 $5.5 \%$ のあな注入して検討し た。

(1) 食塩 (以下 $\mathrm{NaCl}$ と記す) $22.0 \%$ ，覀硝酸ナトリ ウム（以下 $\mathrm{NaNO}_{2}$ と記す） $1,000 \mathrm{ppm}$ を基本塩漬绪と して含み，これに 4 段階の濃度 $(0,1.1,3.3,5.5 \%)$ の重 合リン酸塩混合物(トリポリリン酸ナトリウム：一キサ メタリン酸ナトリウム：ピロリン酸ナトリウム $=75: 15:$ 10, 以下 P-mix と記す）からなるピックルをマルチタ イプピックルインジェクター（インペックスケミカル社 製，渦潮而型）で肉中に $10 \%$ 注入した（これによって 各処理区の肉中には $\mathrm{NaCl} 2 \%, \mathrm{NaNO}_{2} 100 \mathrm{ppm}$ が合 まれると共に P-mix がそれぞれ $0,0.1 ， 0.3 ， 0.5 \%$ 含まれる)。

(2) $\mathrm{NaCl} 15.3 \%, \mathrm{NaNO}_{2} 766.7 \mathrm{ppm}$, それに 4 段階 浱度の P-mix (0, 0.8, 2.3, 3.8\%) からなるピックル を肉中に $15 \%$ 注入した(これによって各処理区の肉中
には $\mathrm{NaCl} 2 \%, \mathrm{NaNO}_{2} 100 \mathrm{ppm}$ 及び P-mix がそれ ぞれ $0,0.1,0.3,0.5 \%$ 含まれる)。

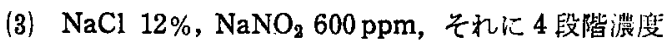
の $\mathrm{P}-\operatorname{mix}(0,0.6,1.8,3.0 \%)$ からなるピックル它 $20 \%$ 注入したにれによって各処理区の肉中には $\mathrm{NaCl} 2 \%$, $\mathrm{NaNO}_{2} 100 \mathrm{ppm}, \mathrm{P}-\mathrm{mix}$ がそれぞれ 0, 0.1,0.3,0.5 \%含まれる)。

ピックル注入後, 試料は 1 個ずつポリェチレン袋に入 れ, 約 $5{ }^{\circ} \mathrm{C}$ で 20 時間保存後分析に供した。

\section{2. 分析方法}

（1）食塩含量：前報 ${ }^{11}$ に示した方法で分析試料を調製 した。そして $5 \mathrm{~g}$ を科量して前報 ${ }^{111} に$ 示した方法で分析 Lた。

（2）保水力：（1）に示した細切肉 $40 \mathrm{~g}$ を $10 \mathrm{~g}$ ずつ 4 本

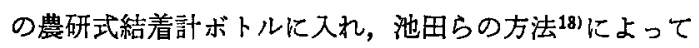
保水力を求めた。

(3) $\mathrm{pH}$ 值：(1)に示した細切肉約 $5 \mathrm{~g}$ を蒸留水 $50 \mathrm{ml}$ と共にブレンダーで均一化し，7,000 rpm で約 5 分間遠

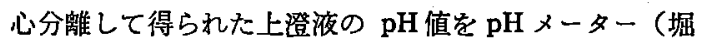
場製，F-7ss）で測定した。

（4）覀硝酸根残存量：前報 ${ }^{11)}$ に示した方法によった。

(5) 発色率: 前報 ${ }^{11)}$ に示した方法によった。

(6) 肉色の測定：P-mix の添加量が異なる各処理区 からそれぞれ 5 試料ずつ試驗に供した。個体の影響をで きるだけ少なくするために，5個体をそれぞれ 4 分割し て各処理区にあてた。ビックル注入後 3 日経過した塩漬 肉を笳線維を横断するように切り，一定の肉片（長さ約 $5 \mathrm{~cm}$, 幅約 $13 \mathrm{~cm}$, 厚さ約 $7 \mathrm{~cm}$ ) Kし, ポリェチレン

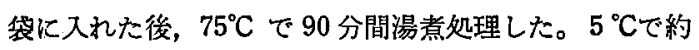
15 時間冷却した後, 切断直後の断面の Hunter L, a な らびに b 值を色差計（日本電色製，ND 101 D 型）で測 定した。

(7) $\mathrm{NaNO}_{2}$ 添加量の推定：前報 ${ }^{11)}$ に示した方法によ った。

（8） P-mix 添加量の推定：(7)と同様の方法によった。

（9）無機リンの分布：ピックル注入直後の塩潰肉を $-20^{\circ} \mathrm{C}$ 通風式冷凍庫に入れて凍結した後, 図 1 亿示子 ように分析に必要な最小限の大きさに切った。すなお 方，䄪 $1 \mathrm{~cm}^{8}$ に切って精科した後，セミミクロケルダー ル分解フラスコに入れ，A.O.A.C. 法14で湿式分解し, Gomori法 ${ }^{16)}$ で発色させて無機リン含量を測定した。そし て五酸化リンとして表示し，その分布状態を検討した。 


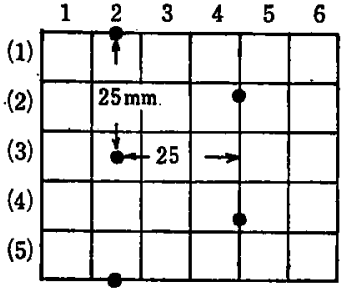

(a)

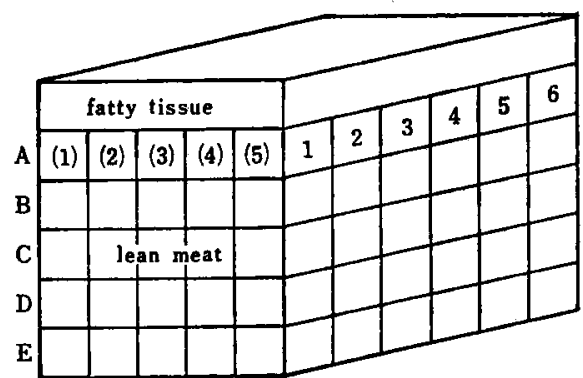

(b)

Fig. 1 Schematic representation of position of injected needles and cut-pieces sampled for assaying of inorganic phosphate

(a) Position of needles injected in loin.

Dots indicate the position of needle.

(b) Cut way to take samples for assaying of inorganic phosphate.

\section{結果と考察}

\section{1. 保水カに及ぼす P-mixの影響}

ビックルを注入する塩漬法で注，肉の保水力はビック ルの注入率, $\mathrm{NaCl}$ 浱度, 重合りン酸塩濃度によって主 に影響される。

本実験では肉中の $\mathrm{NaCl}$ 濃度をおよそ $2 \%$ に保持 し，ビックル注入率と重合リン酸塩添加量を変えて保水 カに対する影響を調查した。供試肉の個体や部位によっ て注入率に差異を生じたが，ほほ次のような傾向が認め られた。その結果を図 2 に示す。
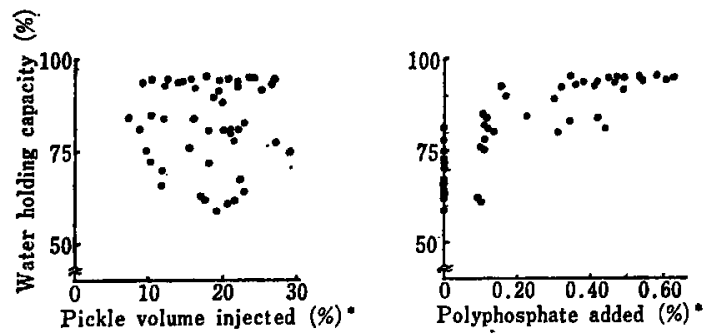

Fig. 2 Effects of injected pickle volume and added polyphosphate level on water holding capacity

*: Estimated on the basis of $\mathrm{NaCl}$ concentration in lean meat.

ピックル注入率と保水力の関係では，注入率の多少に 関俰なく 58〜95\% の保水力を示し，両者間に相関は成 立しなかった。一方, P-mix 添加量と保水力との関係で は $1 \%$ 水準で有意に相関が認められた $(r=0.818)$ 。すな わち、P-mixを添加しない状態では保水力は個体,ビック
ル注入率, $\mathrm{NaCl}$ 含量などの差異によって影響され，ほほ 58 80\% の範囲に分散していた。そして P-mix を約 $0.1 \%$ 添加した時には，個体によって添加効果が異なっ ていた。P-mix 無添加の時に 比較的高い保水力宗し た試料に対しては0.1\%でるかなり勃果的に作用した。 0.3\% 添加では個体差に関係なく大半の試料で $90 \%$ 以 上の高い保水力を示し， $0.5 \%$ 添加ではほとんどの試料 で $90 \%$ 以上の保水力を示し，ほほ安定な状態を示し た。しかし，ピックル注入率が高い試料で到 P-mix の添加効果が弱く，0.1\% 添加ではほとんど効果がな く，0.3\% 添加で効果が明らかとなり，0.5\% 添加でほ とえどの試料が $90 \%$ 以上の保水力を示した。したがっ $\tau$, 安定な保水力を得るには $0.3 \%$ 以上の添加が必要で あった。

WIERBICKI $5^{6}$ 仕 $\mathrm{NaCl}$ 省 2 \%化保ち,トリポリリン 酸ナトリウムとピロリン酸ナトリウム添加量を変光，肉 の加熱収縮率からそれぞれの重合りン酸塩の保水力を調 査している。その結果によれば, 重合リン酸塩無添加試 料の収縮率が約 $18 \%$ であったのに対して 12.3 ミリモ ル(トリポリリン酸ナトリウムでは $0.45 \%$ ，ピロリン 酸ナトリウムでは $0.33 \%$ に相当) 添加の時にほほ最低 の収縮率（約 $6 \%$ ）を示したとしている。また，他の報 告581では $\mathrm{NaCl}$ に少量の重合リン酸塩を添加すること は有効であるとしている。そしてイオン強度が 0.4 以上 ではじめて䨘合リン酸塩の保水効果が顕著であると言る

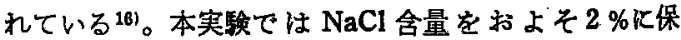
持し，イオン強度を 0.4 以上に維持して肉の保水力をか なり高い状態にまで上昇させたために保水力に対してピ 
Table 1 Effect of added polyphosphate levels on the color characteristics of cooked cured pork loin

\begin{tabular}{|c|c|c|c|c|c|c|c|}
\hline & & \multirow{2}{*}{$\begin{array}{l}\text { Number } \\
\text { of } \\
\text { Samples }\end{array}$} & \multicolumn{3}{|c|}{ Hunter values } & \multirow{2}{*}{ Saturation* } & \multirow{2}{*}{ Hue** } \\
\hline & & & $\mathbf{L}$ & $a$ & b & & \\
\hline Added & 0 & 5 & $61.2 \pm 0.9$ & $9.7 \pm 1.2$ & $6.1 \pm 0.3$ & 11.5 & 32.1 \\
\hline Polyphosphate & 0.1 & 5 & $60.1 \pm 1.2$ & $9.9 \pm 1.0$ & $6.1 \pm 0.2$ & 11.6 & 31.4 \\
\hline \multirow[t]{2}{*}{$(\%)$} & 0.3 & 5 & $60.3 \pm 0.8$ & $9.7 \pm 1.5$ & $6.1 \pm 0.4$ & 11.5 & 32.1 \\
\hline & 0.5 & 5 & $59.0 \pm 1.5$ & $9.6 \pm 1.4$ & $5.5 \pm 0.3$ & 11.1 & 29.5 \\
\hline
\end{tabular}

$* \sqrt{a^{8}+b^{2}} \quad * * b / a$

ックル注入率が有効に作用せず，重合リン酸塩添加量が 顕著に作用したと考えられた。したがって，重合リン酸 塩の保水効果を有效に利用するにはイオン強度をある水 潐以上に保つ必要があるが, 重症の PSE 豚肉には初果 がない17ことから肉の品質を考虑する必要があった。

\section{2. 加熱塩清肉色に及ぼす P-mix の影響}

日本農林規格に基づく格付榆查で注官能的に赤紫色を している製品の增加が指摘されている。この赤紫色はト リポリリン酸塩の影響とされ ${ }^{18)}$, 添加量の影響と考えら れたので，肉色の変化を調査した。その結果を表 1 に示 †े

P-mix を 0.1 及び $0.3 \%$ 添加した加熱塩漬肉色は無 添加のるのと比較してL値がやや低かったが， a , b 值 は共に顥著な変化分観察されなかった。 $0.5 \%$ 添加した 製品では L, b 值が共化著しく低下した。a 值は低下の 傾向を示しただけであった。b值が低下したことによっ て彩度 $\left(\sqrt{\mathrm{a}^{2}+\mathrm{b}^{2}}\right)$ が小さくなり, 色相 (b/a) む小さく なった。色相が小さくることは紫色方向への色の移動 を意味するので，赤紫色化の可能性を示唆するるのと理 解された。しかし，肉眼的に観察された色の差ほど則定
值では表現されていなかった。

一般的には重合リン酸塩の添加によってL值が低下 (6)778)，a 值が高くなる 9118) と報告されているが， a 值 の変化は本結果とは一致しなかった。

3. 覀硝酸根残存率と発色率に及ぼす P-mix の影響 P-mix 添加量と亜硝酸根 (以下 $\mathrm{NO}_{2}^{-}$と記す) 残存 率及び発色率との関係を調べた結果を表 2 亿示す。

P-mix 無添加試料では前報11で得られた結果とほほ 同じ $60 \%$ の $\mathrm{NO}_{\overline{2}}^{-}$残教率と約 $74 \%$ の発色率を示した。 そして P-mix 添加量が 0.1，0.3\% の時にはその添加 量に応じて $\mathrm{pH}$ がほほ直線的に上昇し, それに伴って $\mathrm{NO}_{2}^{-}$残存率も約 $70 \%$ に上昇した。一方，発色率はほほ 直線的に低下し，掣添加試料に比べて約 $7 \%$ 低下した。 さらに $0.5 \%$ 添加した時には $\mathrm{pH}$ はすすが上昇し， $\mathrm{NO}_{-}^{-}$ 残存率むかずか比上昇したのに対して発色率は著しく低 下して約 58\%を示した。

前項で P-mix $0.5 \%$ 添加した時, 彩度が小さくな って色の讶えが低下する結果を得たが，これ悦発色率の 低下に基因すると想定された。

前報11)では $\mathrm{NO}_{2}^{-}$垡存染と発色率に関係する要因とし

Table 2 Effect of added polyphosphate level on $\mathrm{pH}, \mathrm{NO}_{2}^{-}$remaining ratio and color forming ratio

\begin{tabular}{cc|ccccc}
\hline & & $\begin{array}{l}\text { Number } \\
\text { of samples }\end{array}$ & $\begin{array}{c}\text { Added poly- } \\
\text { phosphate level(\%)* }\end{array}$ & pH & $\begin{array}{c}\text { NO } \\
\text { ing ratio(\%)** }\end{array}$ & $\begin{array}{c}\text { Color form- } \\
\text { ing ratio(\%)*** }\end{array}$ \\
\hline Added & 0 & 8 & - & $5.51 \pm 0.07$ & $59.3 \pm 5.5$ & $73.7 \pm 3.5$ \\
Polyphosphate & 0.1 & 8 & $0.12 \pm 0.02$ & $5.64 \pm 0.11$ & $63.0 \pm 6.0$ & $71.4 \pm 7.1$ \\
(\%) & 0.3 & 8 & $0.36 \pm 0.06$ & $5.88 \pm 0.12$ & $70.3 \pm 5.7$ & $66.4 \pm 5.9$ \\
& 0.5 & 8 & $0.56 \pm 0.11$ & $5.95 \pm 0.15$ & $73.3 \pm 6.6$ & $57.4 \pm 8.0$ \\
\hline
\end{tabular}

\footnotetext{
* estimated on the basis of $\mathrm{NaCl}$ concentration in lean meat

** $\mathrm{NO}_{2}^{-}$remaining ratio $(\%)=\frac{\text { residual } \mathrm{NO}_{2}^{-} \text {level }(\mathrm{ppm})}{\text { added } \mathrm{NO}_{2}^{-}} \times 100$

(added $\mathrm{NO}_{\overline{2}}^{-}$level was estimated on the basis of $\mathrm{NaCl}$ concentration in lean meat)

*** color forming ratio (\%) $=\frac{\text { nitroso heme pigments (ppm as hematin) }}{\text { total heme pigments (ppm as hematin) }} \times 100$
} 
て筋肉の内因性物質による還元作用を無視できないこと を示したが，本結果では P-mix 添加量が大きな影響を 与えているるのと判断され, P-mix 添加量と $\mathrm{NO}_{2}^{-}$残 存率との間には 5 \%水準で, P-mix 添加量と発色率と の間には 1 \% 水準でそれそれ相関が成立した。また， $\mathrm{NO}_{2}^{-}$残存率と発色率との間にも $1 \%$ 水準で相関が成立 した。

従来から肉の保水性を良くするリン酸塩（ビロリン酸 塩,トリポリリン酸塩）はいずれも例外なく肉製品の発 色に対し筫に作用するとされている199。森ら201はトリポ リリン酸塩，ピロリン酸塩の混合物 $0.5 \%$ を豚肉などに 添加し，いずれの肉です $\mathrm{NO}_{2}^{-}$残存率が高いととから $\mathrm{pH}$ の上昇がそれに直接関係したと推定している。本結 果では， $\mathrm{pH}$ の上昇と $\mathrm{NO}_{2}^{-}$残存率の上昇傾向がほほ一 致する一方で，それに対応して発色率が低下した。重合 リン酸塩は直接亜硝酸塩を分解する作用を持っていな い21) こくら, $\mathrm{pH}$ の変化が $\mathrm{NO}_{2}^{-}$残存率, 発色率の变 化に直接関与していたと判定された。

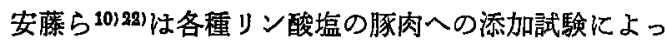
$\tau \mathrm{pH}, \mathrm{NO}_{2}^{-}$残存率, 発色の関係を調查している。そ の結果では肉の $\mathrm{pH}$ を高めるビロリン酸 4 ナトリウム, トリポリリン酸ナトリウムなどは $\mathrm{NO}_{2}^{-}$残存率が高く， 発色状態が悪い結果を示し, pHを低下させるピロリン酸 2 ナトリウム, へキサメタリン酸ナトリウムなどは $\mathrm{NO}_{2}^{-}$ 残存率が低く，良好な発色状態を示したと報告した。

$\mathrm{NO}_{2}^{-}$の分解が肉製品の発色に必須であるが， $\mathrm{NO}_{2}^{-}$残 存量と発色との高い相関ならびにこれらの程度に $\mathrm{pH}$ 大きく関与するという結論は本結果と良く一致した。

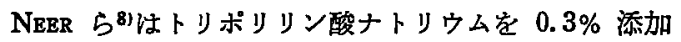
した塩漬豚肉製品は $0.5 \%$ 添加の製品より官能評価が高 いと報告しているととから，過剩な重合リン酸塩の添加 は品質を低下させる可能性が大きいことが想定された。

4. 無穖リンの分布
著者らは以前に食塩の分布状態から注入されたビック ルが部分的に偏在することを明らかにした。食塩と同棁 に重合リン酸塩が偏在するとむしろ品質を低下させるこ とが懸念されるので，その分布状態を調查した。実験方 法で示したような限定された条件下における結果を表 3 に示寸。表示の五酸化リン (以下 $\mathrm{P}_{2} \mathrm{O}_{5}$ と記す) 合量が やや高いのは肉由来のリンを含むと共に注入されたビッ クルのほとえど全量が赫肉部分に注入されたためと考え られる。

本絬果によれば，図1亿示した各層の平均値間に差が 認められ，特に最下層Eが低い值を示した。これは注射 針の先端から $5 \mathrm{~mm}$ と $10 \mathrm{~mm}$ の高さにビックル啫出口 があることによって生じた不均一な分布と推定された。 この傾向は食塩の分布状態とも一致した ${ }^{23)}$ 。P-mix は 分子棈造上䄪 $60 \%$ の $\mathrm{P}_{2} \mathrm{O}_{5}$ を食有するので，この平均 値間の源度差の $0.2 \%$ \&-mix の $0.33 \%$ 飞相当 し，無視できない差であった。また，標準偏差値む P-mix 濃度として 0.2〜0.3\%の差が一般的であるこ とを示していた。部分的な偋在はこれらの層間だけでな く，注射針が㨂入された個所からやや離れた周辺部で高 いリンの存在を示す傾向があった。さらに局部的には小 肉片の最高值と最低值に $0.75 \%$ の差があり，乙の漕度 は P-mix 1.3\% に相当するので, この差が P-mix の 偏在によって生じたるのとすると部分的には相当の差が あることが明らかとなった。

添加された重合りン酸塩が局部的に偏在することによ って浱度の高い部分では前項 $2 ， 3 て ゙$ 示したように $\mathrm{NO}_{2}^{-}$残存率が高く，低い発色状態を極端に発現すると 考光られた。したがって，重合リン酸塩濃度の高いピ。 クルを注入することはこれらの久点を強く助長して品筫 の低下を招くものと想定された。しかし，食塩の分布 差を少なくする一方法として適用される塩清期間の延 長，その他タンブリングマシンやマッサージマシンによ

Table 3 Distribution of inorganic phosphate $\left(\mathrm{P}_{2} \mathrm{O}_{6} \%\right)$ *

\begin{tabular}{|c|c|c|c|c|c|}
\hline Layer** & Number of pieces & Mean (\%) & Standard deviation & Maximum (\%) & Minimum (\%) \\
\hline A & 30 & 0.79 & 0.17 & 1.12 & 0.51 \\
\hline B & 30 & 0.84 & 0.16 & 1.12 & 0.57 \\
\hline $\mathrm{C}$ & 30 & 0.77 & 0.13 & 1.12 & 0.53 \\
\hline $\mathrm{D}$ & 30 & 0.71 & 0.09 & 0.88 & 0.52 \\
\hline E & 30 & 0.64 & 0.12 & 1.00 & 0.37 \\
\hline Whole & 150 & 0.75 & 0.15 & 1.12 & 0.37 \\
\hline
\end{tabular}

Operating conditions: pressure $3.0 \mathrm{~kg} / \mathrm{cm}^{2}$, belt speed $2.5 \mathrm{~m} / \mathrm{min}$

* Contained natural phosphate in lean meat

** The location of each layer is represented in Fig. 1. 
って肉組織伅物理的衝繋を与えて分散を促進することで これらの欠点の発現を少なくすることができると考えら れる。前述の通り, 重合リン酸塩淟度が高い状態では $\mathrm{pH}$ 上昇による低い発色状態を避けることができないの で前項 2,3で得られたように，0.3\% 以上の添加は好を しくないと考えられた。

\section{要 約}

本研究はマルチタイプピックルインジェクターを使用 してハム類を製造するために必要な技術的基本条件の確 立を目的に実施した。重合リン酸塩は製造上不可欠な添 加物ではないが，低食塩の製品が好まれることや冷凍肉 を利用することが多くなったことによる保水力低下を補 うため，必要性は高まっていると考えられた。そこで， トリポリリン酸塩を主体とする重合リン酸塩混合物を添 加して影響を調查した結果，次のことが明らかとなっ た。

(1) 食塩含量をほほ $2 \%$ に保持して肉の保水力に対す るピックル注入率と重合リン酸塩添加量の影響を調查し た結果，重合リン酸塩添加量は $1 \%$ 水淮で有意に影響し た。そして $0.3 \%$ 以上の重合リン酸塩添加で保水力は 90\% 以上の值を示し，ほぼ安定した。

（2）加熱塩漬肉色は重合りン酸塩添加量が少ない時は ほとえど影響されなかったが，0.5\% 添加では $\mathrm{L}, \mathrm{b}$ 值 が著しく低下した。

(3) 重合リン酸塩は $\mathrm{NO}_{2}^{-}$线存率, 発色率に有意に影 響し，添加量の増加は $\mathrm{NO}_{2}^{-}$残存率を高文発色率を低 下させたが，0.5\% 添加では発色率の低下が顥著であっ た。

(4) 注入された重合リン酸塩は肉の内部で偏在した。 そのため，浱度の高い部分は品質低下の可能性が示㗘さ れた。

本試駼を終始御指導下さった丸州大学農学部深沢利行 教授汇深誧致します。また，ての研究の一部は(財)食品 座業センターの研究委託事業として実施した。

$$
\text { 文献 }
$$

1) GISsKe W.: Fleischwirtschaft, 10, 21 (1958).

2) KenderesKIM: Fleischwirtschaft, 13, 818(1961).
3）新村 裕 - 高坂和久：日本食肉加工協会試䀢成縝 書, No. 14, 62 (1978).

4）山田順一・仲田久雄・佐々木道夫・藤井静江・春 日谷郷子・新对 裕・高坂和久：日本食肉加工協 会試験成績書, No. 14, 1 (1978).

5）大橋登美男・营野 栄：栄養之食粗，26，497 (1974).

6) Wierbicki, E., Howker, J.J. and Shults, G.W.: J. Food Sci., 411116 (1976).

7) Schwatz, W.C. and Mandigo, R.W.: J. Food Sci., 41, 1266 (1976).

8) NeER K.L. and Mandigo, R.W.: J. Food Sci., 42, 738 (1977).

9）仲田久雄：日本食肉加工協会試験成縝書, No. 10, 41 (1974).

10) Ando, N., Kako, Y., Nagata, Y., Ohasht, Hirakata, Y., Suematsu, N. and Katamoto, E.: Bull. Meat and Meat Prods., 2, 1 (1963).

11）新村 裕・山田䐓一・藤井静江・朝日谷哏子・高 坂和久：日食工誌，28，284 (1981).

12）寺田一彦：推測統計法(朝目書店)， p. 167(1970).

13）池田敏雄・中井博康・齐藤不二男・安藤四郎: 畜 産試験場研究報告, 30,63 (1976).

14) Official methods of Analysis, A.O.A.C., 12 ed., p. 11 (1975).

15）小原㫪二郎・鈴木隆雄・岩尾裕之編：食品分析八 ンドプック (建帛社)，p. 263 (1969).

16) Hellerdoorn, E.W.: Food Technol., 16, 119 (1962).

17）朴 亨基・伊藤䛨躬・深沢利行：日畜会報，46， 360 (1975).

18) Davis, C.E., Townsend, W.E. and Mercuri, J.: J. Anim. Sci., 41, 1632 (1975).

19）天野慶之・安藤則秀・橋本吉雄・橋本芳郎・藤巻 正生・右田正男・矢野幸男：食肉加エシリーズ， 2 ・食肉加エのニニットブロセス（光琳書院）, p. 47 (1963).

20）森 一雄 - 山本泰男 - 赤羽義章 - 大蒖末和：日水 誌, 38, 1383 (1972).

21）永田 致治・安藤 則秀： 栄養と食精， $24 ， 489$ (1971).

22) ANdo, N., KaKo, Y. and Nagata, Y.: Bull. Meat and Meat Prods., 1, 1 (1961).

23) 新村 裕 - 山田㮌一・藤井静江・春日谷郷子 - 高 坂和久：食品産業センター技術研究報告（投穆 中).

（昭和 55 年 12 月 11 日受理） 